\title{
Traditional Role In The District Surabaya
}

\author{
Siwidyah Desi Lastianti \\ Universitas Merdeka Surabaya \\ Email: Siwi.dy@gmail.com
}

https://doi.org/10.30741/wiga.v9i1.427

I N F O ART I K E L

Tanggal masuk:

26 Februari 2019

Tanggal Revisi :

16 Maret 2019

Tanggal Diterima :

31 Maret 2019

\begin{abstract}
A B S T R A C T
This study aims to determine: (1) the district government Surabaya in determining the block in Citra Niaga Market location Surabaya; (2) the implementation of the allotment of Block G-2; (3) increase in local revenues derived from market sectors. The data used is data 2003 to 2005 from the Office of Market and Regional Financial Management Agency Surabaya. Primary data has also used that data obtained from the heads of the market and traders in Citra Niaga Market Surabaya. The results of this research are: 1) the efforts made by the government in overcoming the problems Surabaya by: (a) re-creating the kiosks/stalls in block G-2 is optimal; (b) rearranging merchants to trade freely in the street Seroja to enter into site Citra Niaga Market Block G-2; (c) issuing policies related to the market environment is clean, beautiful and comfortable; (d) issue a policy concerning Retribution in block $G-2$, which is equal to the Retribution rates for merchants selling goods on the street Seroja (behind the market Citra Niaga), this will affect the selling price of goods sold by traders in the block $G-2$ is equal to the selling price of the merchant on the street Seroja; (e) provides that a policy of cheap money installments for traders in block $G-2$ that will be able to attract other merchants to hire kiosk / Los block the G-2; (2) Contributions Retribution Citra Niaga to the PAD market is still small, need to be improved.
\end{abstract}

Keywords: government policy and PAD district

\section{INTRODUCTION}

One of the goals to be achieved in Surabaya Year Strategic Plan 2004 - 2008 is to improve the quality of facilities and infrastructure of the macro region Bert Juana to improve the distribution and the distribution of development outcomes. The final impact is expected later was reduced disparities between regions in Surabaya through equitable distribution of economic infrastructure, in addition to realizing sustainability damn environmental balance, as well as efforts to realize the process of sustainable development (sustainable development). The purpose of providing economic infrastructure is adequate as an effort to empower Small and Medium Enterprise community in strengthening the sources of public revenue. In this case, the market became places increased economic business for the distribution of items of trade that could eventually spur household incomes and improve social welfare.

Public construction of facilities such as schools, health centers and markets geared to servicing the needs of the community as part of the public service. One of the public facilities that had been prepared by the Government of Surabaya to the street vendors in traditional markets (market Legi) 
Surabaya is Citra Niaga Market Building Surabaya. However, in development for more than a decade data, not all facilities have been built in Citra Niaga Market exploited well, such as the G-2 block. Blok G-2 is upstairs Block G Market Citra Niaga intended for wet commodities such as meat, fish, vegetables and draconian. Kios/los in Block G-2 is only partially functioning, only the meat traders who actually use the meat room facilities at the Block G-2. This is because most of the stall owners/loss had moved to another place by reason of their income dropped significantly after the market temporarily in Jalan Seroja (d/ h Jalan Ampera) and the general area Market Citra Niaga such as sidewalks, parking, road shoulders and on-site entertainment stage, resulting sepia buyers during the hours effectively market.

Non-functioning of the market Citra Niaga Blok G-2 on the 2nd floor caused by (1) Buyers prefer to buy in the old traditional markets (on the back of market Citra Niaga); (2) The buyer lazy to go to the floor 2. This condition causes the loss of income trader at the 2 nd floor of block G-2 Market Citra Niaga. Because of the decreasing revenue, causing a delayed installment payments. This condition should get the attention of the Government of Surabaya and not let the neighborhood looks rundown and smelly because of there in place. By the background above, this study takes the title: Traditional Role In In The District Surabaya. Reasons for selecting titles are: (1) This research has not been there that do; (2) Research is often done with regards to the contribution of traditional markets in increasing PAD; (3) Most research on the effectiveness and market retribution against $\mathrm{PAD}$.

Formulation of the problem which is the focus of interest in this study includes: (1) What efforts have been made by the Government of Surabaya in addressing the problem placement kios/los in Block G-2 Citra Niaga Market Surabaya. (2) How big is the contribution of market retribution Citra Niaga to local revenue (PAD)? The purpose of this study includes: (1) What efforts have been made by the Government of Surabaya in addressing the placement of kiosks/loss in Block G2 Citra Niaga Market Surabaya. (2) How big increase local revenue (PAD) derived from traditional market retribution Citra Niaga Market Surabaya.?

The expected results of this study are: (1) can be used as a Vahan consideration or input by Surabaya District Government agencies, especially the market in the decision making related premises optimization local revenues derived from the Retribution market. (2) for the traders can be used as a Vahan consideration to occupy loss / kiosk that had been prepared by the District Government to consider the cleanliness, price, and revenue to be obtained. (3) to other researchers, can be used as Vahan reference in other similar studies.

Implementation of Law No. 32 of 2004 and Act No. 33 of 2004 has to lead to profound changes regarding the administration of central and local relations, particularly in the field of public administration and the financial relationship between central and local governments known as regional autonomy, Financial balance between the center and regions constitute a comprehensive system in order to finance the implementation of the principle of decentralization, deconcentration, and assistance. By Sidik (2003) decentralization can be divided into four types: (1) Political Decentralization: granting rights to citizens through elected representatives. A strong power to make the decision public. (2) Administrative Decentralisation: delegation of authority that aims to redistribute authority, the responsibility of financial resources for the provision of public services. (3) Fiscal Decentralization: delegation of authority that includes self-financing or cost recovery in the provision of public services, cofinancing or coproduction of users of public services, increased taxing power, transfer and share the results as well as the freedom to borrow. (4) Decentralized Economy: authority associated with economic policy decision making that focuses on economic efficiency in the provision of public goods through liberalization, privatization, and deregulation which is in line with market economic policies.

In Law No. 32 of 2004 and Article 107 of Law No. 33 of 2004 in Article 5 mentioned regional revenue sources include: (a) Local Revenue hereinafter called PAD, namely: Results of Local 
Taxes, Retributions Results Results wealth management area that is separated, Miscellaneous local revenues are legitimate; (b) Balance Fund; (d) Other regional revenue legitimate. In the context of the market economy means the context of meetings between sellers and buyers of goods and services. (Sayekti, 2004). The behavior of buyers and sellers in the market will always be influenced by the structure of the market that will be faced by the seller and the buyer. Some terms of market structure that can influence consumer behavior as buyers and producers as sellers, among others: (1) Total sales and wider distribution of sellers in the market; (2) type of homogeneous or heterogeneous goods; (3) The ability of the seller to influence the market; (4) knowledge of the seller and buyer will market it faces; (5) Whether or not it easy for new companies to enter the market of traditional markets is also called the people's market, namely the market that the seller is the people who belonged to low income, medium and high, and buyers also come from the same group. Traditional forms of building market are still very simple and the price is determined on the basis of bargaining. Traders in this market do not hire kios/los but enough to pay the Retribution market.

While the modern market is one of the markets already uses a magnificent building and the seller must hire kios/los for a place to sell. Prices have been set by the seller. Buyers not as a determinant of price. Traditional markets are still in great demand by the buyers because buyers think that if you buy at the traditional market price of the goods sold are still affordable by middle-income shoppers down, and all the basic necessities available. In the traditional market developed never deserted from buyers. In accordance with law No. 33 of 2004 on Financial Balance between Central and Local Government stated that the source of local revenue consists of the results of local taxes, the result of retribution, the results of the company belonging to the area and the results of the management of the wealth of other areas that are separated and others -Other legitimate local revenues. Local revenue (PAD) is only one component of the country's financial revenue source in addition to other income in the form of equalization funds, loans and other areas of legitimate receipts also the rest of the previous year's budget can be added as a source of funding in the area of governance. Overall admissions each year are reflected in the local government budget.

Definition of revenue (PAD) that is income derived from an area that includes the results of local taxes, the result of retributions, local corporate results, the results of which are separated regional wealth management and other legitimate PAD. PAD is one source of regional revenue that has the potential for increased acquisition by way of extensification and intensification. Management of PAD transparent and accountable will encourage increased local revenues. The sources of revenue PAD one of which comes from the Retribution of market management. Each region has a different revenue generation potential. Agriculture-based areas will vary its revenue generation potential with the area-based industry and trade. For the areas of agriculture based on the general potential of local revenue would be lower than in industry or commerce. Therefore, the regional government should be able to optimize the acquisition of PAD, so that per capita income of the population increased from year to year and people's purchasing power will be intensified. To obtain optimal PAD, it is necessary to the management of the resources can be used more optimally and carry out excavation potential resource potential area. This is done because PAD is a source of revenue that is relied upon to indicate that the area is capable of independent or not. If the results of the PAD is greater than the acceptance of donations area, then this indicates that the region is able to live independently and be able to implement regional autonomy without feeling forced.

Understanding regional autonomy under Law No. 32 of 2004 (2004) is an autonomous regional authority to regulate and manage the interests of the local community at its own initiative based on the aspirations of the people in accordance with the legislation. The purpose of regional autonomy according to Smith (in Yuliati, 1985) in the analysis of CSIS expressed by Syarif Hidayat distinguished from the two sides interests, namely; (1) From the Central Government, the main 
objective is political education, leadership training, creating political stability and realize the democratization of the system of government in the area. (2) In terms of local government, there are three main objectives, namely (a) to realize what is referred to as political equality,meaning that through regional autonomy is expected to be more opportunities for people to participate in various political activities at the local or regional, ( b) to create local accountability, meaning the autonomy will improve the ability of local governments to pay attention to the rights of the community, (c) to realize the local responsiveness, meaning that regional autonomy is expected to facilitate the anticipation of emerging problems and also improve acceleration and social development regional economy.

Soegijanto (2001) in a study entitled Analysis of Regional Income Support as a factor of regional autonomy in Mojokerto to produce as follows: 1) Routine Capability Index is not at $100 \%$ so that the PAD has not been able to finance the routine, 2) The proportion of PAD in the mean average reached $33.54 \%$, so it has exceeded the standard by $30 \%, 3$ ) the effect of local taxes, retributions, other income, tax-sharing / non-tax revenue and government grants significant effect on the budget, 4) tax death, the outcome of tax / non-tax revenue is a source of potential to be developed in the future. Asnawi (2003) with a research entitled Regional Autonomy nature Surabaya Regional Financial Perspective produces as follows: 1) The need for fiscal Surabaya district is at 147.64 times greater than the average standard fiscal needs of East Java, this indicates that the level of government dependency the area of the central government is very high, 2) Fiscal capacity Surabaya by 21 times compared with the average fiscal capacity of East Java standards, 3) elasticity PAD to the GDP at constant prices (with oil) Surabaya demonstrate the value of -8.84, this means that the rate of GDP growth is very influential on PAD, PAD and elasticity to the GDP at current prices (oil and gas) shows the value of 0.56 , this means that the growth rate of GDP based on the price of oil and gas apply with less effect on the increase in revenue.

Research conducted by Haryotejo B (2014) the results showed that the contribution to the GDP of non-oil more traditional markets (shop or stall) compared to the modern market. However, the opposite condition happen, that the modern market (supermarkets) in the province, in this case the urban, have a greater contribution to the acceptance of the budget as compared to areas of the city / county. In contrast, traditional markets have non-economic advantages from the standpoint of economic interests macro, namely the provision of a large selection of business opportunities, employment, and contribution to output, although these options may conflict with the interests of local governments to increase local revenue. (Haryotejo 2014).

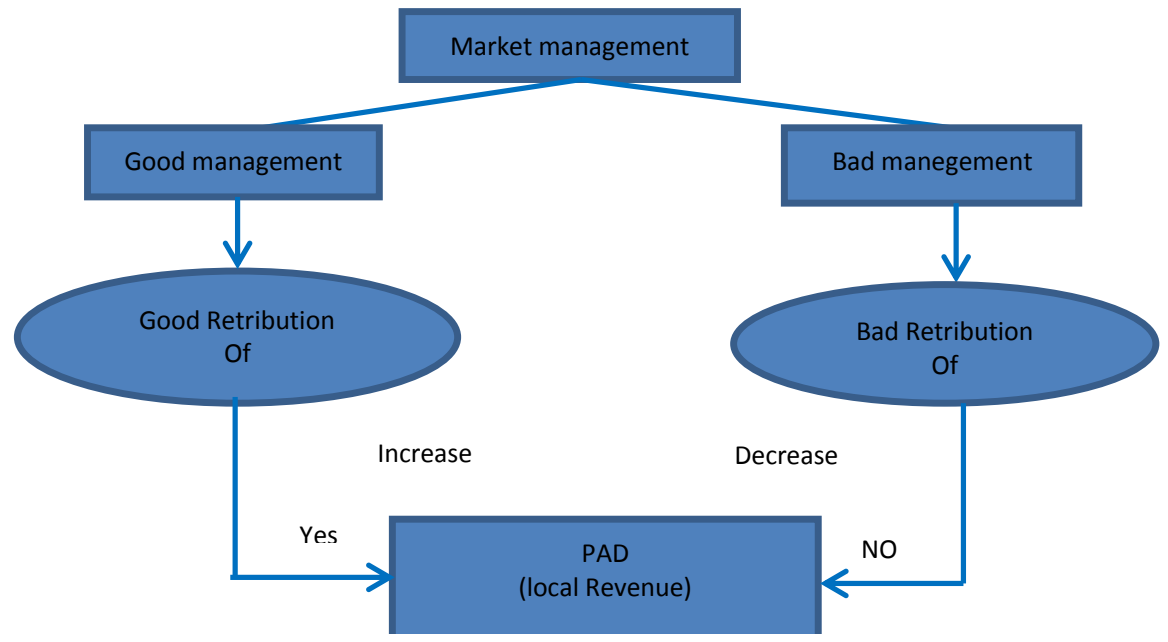

Diagram 1. Research Framework 


\section{RESEARCH METHODOLOGY}

The approach used in this study is a qualitative descriptive approach, namely a study done by providing a quantitative description of the results of qualitative research. (Supranto, 1998). That was the subject of this research is the Government Surabaya Surabaya especially office markets. And the object being studied is Citra Niaga Market Surabaya. The data used in this study are primary data and secondary data. Primary data is data obtained directly from the field. Secondary data was collected and documented by an agency or institution. Data will be used is derived from market services Surabaya, Regional Financial Management Agency Surabaya, and UPTD Citra Niaga Market Surabaya. Data collection is done by (1) interview, (2) observation, (3) documentation. Data analysis method used is descriptive analysis method, the method of analysis only provides an explanation of what efforts already made by the Government of Surabaya in addressing these problems, and provide an overview of the last to know whether the increase in revenue.

\section{RESULTS AND DISCUSSION}

Per Local Regulation, Surabaya No. 12 of 2002 on retributions Market stated that the market is given a certain limit which comprises the top of the page or the court and shaped stalls and or kiosks and other forms of managed by Local Government and is dedicated to the merchant market including compulsory retributions. According to the Regional Regulation on top, merchant acquiring legalization to trade in the Market area Citra Niaga is a merchant in the home store (shop), a trader in the stall Block G-2 and traders in kiosks or loss as well as traders in the food court at Block G-2 that has been signed a joint agreement between the developer with merchants and Local Government at the beginning of placement, not including traders are sitting on the floor in public facilities Citra Niaga Market and Jalan Seroja.

Surabaya District Government efforts in this case represented by the Market Office to address the problems that arise in the Market Citra Niaga Blok G-2, among others: (1) re-creating the kiosks/stalls in block G-2 is optimal; (2) rearranging the merchants who trade freely in the street Seroja to enter into site Citra Niaga Market Block G-2; (3) issuing policies related to the market environment is clean, beautiful and comfortable; (4) issued a policy concerning Retribution in block G-2, which is equal to the Retribution rates for merchants selling goods on the street Seroja (behind the market Citra Niaga), this will affect the selling price of goods sold by traders in the block G- 2 is equal to the selling price of the merchant on the street Seroja; (5) provides that a policy of cheap money installments for traders in block G-2 that will be able to attract other merchants to hire kiosk / Los block the G-2.

Presence market traders Citra Niaga Surabaya will contribute to PAD Surabaya. Therefore, good governance, order and provide security guarantees will encourage merchants to increase revenue. With so many buyers who bought in the market, Citra Niaga will cause traders easier to pay the rent and will reduce the amount of rent unpaid Oleg traders. Good management is needed in this regard. Due to the good management will be able to boost revenue Surabaya. PAD developments derived from the Retribution markets Citra Niaga Surabaya shown in the following table:

Tabel 1. Realization of Market Retribution Revenue in Citra Niaga Market

\begin{tabular}{lllll}
\hline NO & Fiscal Year & Target $(\mathrm{Rp})$ & Realisasi $(\mathrm{Rp})$ & $\%$ \\
\hline 1 & 2002 & $188,009,200$ & $188,582,800$ & 100.31 \\
2 & 2003 & $192,070,000$ & $190,973,680$ & 99.43 \\
3 & 2004 & $182,564,000$ & $191,603,800$ & 104.95 \\
4 & 2005 & $215,616,000$ & $233,958,900$ & 108.51 \\
5 & 2006 & $223,077,000$ & $155,571,700$ & 69.74 \\
\hline
\end{tabular}

Source: Office of Market Surabaya, 2007 
Table 1 shows that the development Retribution revenue realization decreased from 2000 to 2006, from US $\$ 186,857,750.00$ in 2000 down to $\mathrm{Rp} 155,571,700.00$ in 2006 . the decrease is due to (1) decrease in the number of traders who occupy stalls / loose has Citra Niaga; (2) the number of traders who move from stall / los market Citra Niaga into Lotus road or sidewalks that are not authorized; (3) the high cost of rental stalls / loose has Citra Niaga so many traders; (4) The decrease in the number of buyers in the market Citra Niaga on a typical day. From Table 1 it can be seen that the contribution of market retribution against PAD Citra Niaga Surabaya Surabaya from 2002 to 2006 fluctuated, which in 2002 amounted to USD 188,582,800.00, 2003 amounted to USD 190,973,680.00, 2004 of Rp 191,603,800.00 for the year 2005 amounting to $\mathrm{Rp}$ 233,958,900.00 and in 2006 decreased by USD 155,571,700.00. Contributions retribution market Citra Niaga Surabaya against region income Surabaya shown in Table 2 below:

Table 2. Contributions of Retribution Market Citra Niaga Against PAD Surabaya 2002 2006

\begin{tabular}{llll}
\hline Year & Retribution $(\mathrm{Rp})$ & PAD $(\mathrm{Rp})$ & Contribution $(\%)$ \\
\hline 2002 & $188,582,800,00$ & $45.097 .701 .000,00$ & 41,82 \\
2003 & $190,973,680,00$ & $70.114 .758 .577,00$ & 27,23 \\
2004 & $191,603,800,00$ & $44.534 .969 .630,00$ & 43,02 \\
2005 & $233,958,900,00$ & $48.990 .312 .932,00$ & 47,76 \\
2006 & $155,571,700,00$ & $42.144 .160 .000,00$ & 36,91 \\
\hline
\end{tabular}

Source: BPS Surabaya, 2007

Table 2 shows that the contribution derived from the Retribution Citra Niaga to the PAD market during the period from 2002 to 2006 as follows : (1) in 2002 amounted to $41.82 \%$; (2) in 2003 amounted to $27.23 \%$; (3) in 2004 amounted to $43.02 \%$; (4) in 2005 amounted to $47.76 \%$ and (5) in 2006 amounted to $36.91 \%$.

\section{CONCLUSIONS}

From the analysis and discussion on the use of block G-2 Market Citra Niaga Surabaya, it can take several conclusions: Efforts will be made by the Government of Surabaya should soon eventuated because the policy will encourage the growth of merchants who entered into market Citra Niaga Blok G-2 and will encourage buyers to switch appetite to buy from the market that is on its way to the market Seroja Citra Niaga Blok G-2. Management of facilities and infrastructure should be implemented optimally to create a market that is beautiful, clean and comfortable so that traders and buyers will be satisfied. Revenues derived from the Retribution Citra Niaga market would be improved if Surabaya District Government immediately issued a policy in favor of the vendors in the market Citra Niaga. Contributions from Citra Niaga market retribution against region income needs to be improved.

Based on the above discussion in this study proposed some suggestions that can be taken into consideration for the Government of Surabaya in order to increase market Retribution in support of improving PAD, among others. 1) Conduct data collection merchants every year to determine the extent to which the development of the number of traders from year to year. 2) Rearrangement stall / stalls in block G-2. 3) Imposition of Retribution the same amount of traders who sell in the market Citra Niaga with merchants who sell outside the market Citra Niaga. 4) Good law enforcement personnel in particular for peace and security in the market to prevent confusion and chaos in the market so it is not convenient for the seller and buyer activities. 5) To coordinate with relevant agencies in an effort to restore more traders into a 'legal', which has been provided by the local government. Limitations of the study this research conducted by using secondary data, research is only done on the traditional markets. 


\section{REFERENCES}

Ahmad, A. K. (2003). Complete Dictionary ofEconomics. Gitamedia Press, Jakarta.

Bappeda District Surabaya. (2006). the Drafting Team, Utilization Study Block G-2 Citra Niaga Market Surabaya,Surabaya District Development Planning Agency.

Bappeda district Surabaya. (2007). Tim Composer, Final Report: Community Economic Development Plan inSurabaya, Surabaya District Development Planning Agency.

Halim, A. (2001). Anthology of Regional Financial Management.Jogjakarta: UPP AMP YKPN.

Halim, A. \& Abdullah, S. (2004). Local Original Revenue (PAD) as a Source of DevelopmentFinancing, paper presented at the conference IRSA (Indonesian Regional Science Association) to 6 in Jogjakarta.

Haryotejo, B. (2014). Dampak Ekspansi Hypermarket Terhadap Pasar Tradisional Di Daerah. Jurnal Bina Praja, Volume 6(Nomor 3 Edisi September 2014), pp.241-248.

Liao, K.-H. \& Huang, I.-S. (2016). Impact of Vision, Strategy, and Human Resource on Nonprofit Organization Service Performance. Procedia - Social and Behavioral Sciences, 224(August 2015), pp.20-27. Available at: http://dx.doi.org/10.1016/j.sbspro.2016.05.395.

Koswara , E. (2000). Toward Regional Autonomy Implementation Based on Law No. 22 of 1999, Analysis, CSIS, Year XXIX / 2000 No.1.36-53.

Lincoln, S. \& Arsyad. (2008). Research Methodology for Economics and Business, UPP AMP YKPN, Yogyakarta.

The Institute of Public Administration and BPKP. (1999). Socialization Module Accountability System for Government Agencies(AKIP), Jakarta.

Miller, S. M. \& Frank, S. R. (1997). Fiscal Structures and Economic Growth at The State and Local Level, Public Finance Review, Vol 25, No. 2.213- 237

Saad, I. (2003). Implemantasi Autonomous Region has led to distortions and High Cost Economy,Smeru Working Paper.

Santoso, N. (1995). Retribution Market For Local Revenue, Market Case Study Sleman,Prisma Number 4, LP3ES 19-35.

Sarmanu, (2005). Research Methodology, LPPM, Airlangga University, Surabaya,

Suindyah, S. D. (2004). Ekonomi Mikro, Pascasarjana Undar Press, Surabaya.

The Institute of Public Administration and BPKP, 1999, Socialization Module Accountability System for Government Agencies(AKIP), Jakarta.

Wijaya, P., University Team. (2001). Planning Implementation and Evaluation Public discretion,Wijaya Putra University Press, Surabaya. , (2004), Law of the Republic of Indonesia Number 32 Year 2004 on Financial Balance between Central and Local Government, the Directorate General PUOD, Jakarta. , (2004), Law of the Republic of Indonesia Number 33 Year 2004 on Regional Government, Directorate General PUOD, Jakarta. , (2003), Surabaya District Regulation No. 10 Year 2003 regarding the Strategic Plan of Surabaya, Surabaya District Government. , (2004), Surabaya District Regulation No. 27 of 2004 on the Organizational Structure and Work Procedure Markets Department, Government of Surabaya.

(2006), Surabaya District Regulation No. 12 Year 2006 on retributions Market, Surabaya District Government. ,(2005), Surabaya Regent Decree No. 82 Year 2005 on the Establishment of the Organization and Work Procedure UPTD Citra Niaga Market Surabaya, Surabaya District Government. 